\title{
Protein Sel-1 Homolog 3
}

National Cancer Institute

\section{Source}

National Cancer Institute. Protein Sel-1 Homolog 3. NCI Thesaurus. Code C150059.

Protein sel-1 homolog 3 (1132 aa, $129 \mathrm{kDa}$ ) is encoded by the human SEL1L3 gene. This protein may play a role in calcium binding and signal transduction. 